\title{
Integrated Report System in Italian Law
}

\author{
Valter Cantino*, Damiano Cortese ${ }^{* *}$
}

\begin{abstract}
The recent (2016) implementation in the Italian judicial system of the European Directive (2014/95/EU) about the disclosure of non-financial and diversity information by large companies and groups is crucial for understanding the need to manage in a fair approach the transition to a global and sustainable economy oriented to social and environmental principles. The Directive calls for a more concrete proof of social, environmental and ethical concerns that can be guaranteed by integrated tools. Integrated reporting generates impacts at governance level and new set of transparent and intelligible information shared with stakeholders favor their engagement and allow understanding of the social role that the company was always asked to play but not always has properly communicated. Implementing integrated reporting, a company might enhance its performances, increase market rating, build more effective bank-firm relationships, and generate growing value, both in perception and financial.
\end{abstract}

Keywords: Corporate Social Responsibility; Sustainability; Integrated Reporting; Global Markets, Corporate Governance; Stakeholder Relations

\section{Integrated Report System}

In the contemporary scenario, some emerging traits and instances characterize the panorama, both for society and firms. Globalization has changed the perception of boundaries (Brondoni, 2014), affecting firms' productive behaviors due to the increasing complexity of business and related risks. Global markets call for greater and more complex management and for a collaborative governance of supply chains and stakeholder relationships (Vurro et al., 2014; Salvioni \& Astori, 2013; Perrini \& Vurro, 2006). Such condition is combined with a global economic crisis (Brondoni, 2003), financial scandals, bottom-up instances of responsible consumption, and ecological sensitivity. This implies the comeback for factors altered during the years (Vitolla et al., 2016), modifies usual demands and creates new requests from stakeholders, such as attention to and protection of human rights, respect for the environment, economic durability, and consumer protection.

A new role of the private sector and in particular of enterprises as "a decisive factor in influencing environmental performance and long-term environmental sustainability" (Cruz \& Matsypura, 2009) is constantly expanding. Firms cannot

\footnotetext{
*Full professor of Management, University of Turin (valter.cantino@unito.it)

** Lecturer in Management, University of Turin (damiano.cortese@unito.it)
} 
avoid taking into account the impact of their activity, as the actual conditions do not allow indifference to topics that are supranational-for instance, those included in the United Nations' Sustainable Development Goals (2014)—of public domain, interest, and discussion. More broadly, it is clear that "corporations play a critical role in the overall health and functioning of society" (Asif et al., 2011:1). The traditional governmental function in responding to social needs is no longer sufficient, and firms are involved in a greater contribution to find solutions thus far designed at the political level (Jamali \& Mirshak, 2007). Thus, the enterprise becomes a dynamic actor in the development of welfare, overcoming the separation between public and private concerns.

The consciousness of interdependency among economic, social, and environmental purposes has determined an extended conception of firms' charge (Salvioni \& Bosetti, 2014), leading to the new idea of the global responsibility of enterprises (Risso, 2012). According to Asif et al. (2011), the dotted picture of contemporary reality is at its foundation a matter of stakeholder relationships. To be more specific, there is a close connection between sustainable development (Brundtland, 1987) considered as a responsible model of growth combining the continuity of business and a thoughtful use of resources - corporate sustainability and corporate social responsibility (CSR). All these approaches are focused on different levels of stakeholders' relations management. It is neither believed any longer that companies have a univocal and unidirectional instance, namely the exclusive maximization of shareholders value, nor that this orientation is the root of better financial performance. Some myths have therefore been discarded and replaced by the perception of firms' function in and focus on collective and environmental instances (Freeman \& Parmar, 2017; Vurro, 2014; Salvioni \& Astori, 2013; Campbell, 2007). The effectiveness of relationships with stakeholders and, generally, the implementation of social and environmental concerns, has led to an integrated concept of responsibility (Freeman et al., 2010; Salvioni \& Bosetti, 2014).

Looking at the simultaneous social and commercial responsibility of enterprises (Venter et al., 2017) from this point of view, a new demand for transparency is clearly growing. Transparency is the evidence of how and to what extent firms take into account the needs expressed by the market, investors, stakeholders, and consumers. It is therefore the symbol of enterprises' activities as well as a unique opportunity to communicate the sustainable approach, shedding light on governance policies, spreading ethical principles and achieved goals (Salvioni \& Bosetti, 2014). Reporting tools are nodal: it is necessary to reconceptualize them as comparable models of corporate communication.

A significant observation is suggested by Müller (2015): the popularity of sustainability reports has increased since the financial crisis (2008/09). In this regard, however, the acquisition and implementation of new instances in enterprises' daily life and operations must be considered a turning point. The disclosure of these issues should not be relegated to a role of "parachute" for critical moments. Conversely, it must be constant: only in this way can the communication about a sustainable approach become comparable, turning into a steady dialogue with the context surrounding the enterprise and its stakeholders, as a reflection of a consistent sustainable programmatic line.

In addition, the evolution of legislation, particularly at the European level, confirms what is illustrated. On November 15, 2014, the European Directive 95 was published 
as an amendment of previous Directive 34 (EU Directive, 2013), with the aim of increasing the significance, consistency, and comparability of non-financial and diversity information disclosed by defined undertakings and groups. Regarding the disclosure of such non-financial information, the European Parliament emphasizes that it "is vital for managing change towards a sustainable global economy by combining long-term profitability with social justice and environmental protection" (EU Directive, 2014). This remark was already included in previous documents, such as the European Communication "Working together to create new growth" (EU Communication, 2011), in which a future legislative tool for the transparency of social and environmental information provided by companies was proposed as an insurance of the comparability and equality of conditions. The purpose was to promote the development of businesses oriented to more ethical, social, and environmental interests, beyond the "legitimate quest for financial gain" (EU Communication, 2011:14). It is not just a matter of designing, providing, and implementing reporting tools. Vice versa, through these instruments, the aim is to achieve higher purposes. On the one hand, the goal is to create a culture oriented toward sustainable development that must be recorded through appropriate statements. On the other hand, the same tools become elements guiding the governance and management choices. In its resolution on February 6, 2013, the European Parliament acknowledged the relevance of businesses spreading information on sustainability, identifying related risks and opportunities in terms of investors' and consumers' increasing trust. This disclosure combines long-term profitability with social justice and environmental protection goals. Clearly, the proper implementation of corporate social responsibility (CSR) can speed up-in particular during a global economic crisis and in a growing globalized economycustomers' confidence reconstruction and a consequent economic recovery. The typical risk of information asymmetry could be mitigated by good disclosure policies. The "composite, organized and cohesive form" (García-Sánchez, NogueraGámez, 2017) of an integrated report is surely strategic because it provides additional high-value information influencing shareholders when they have to choose where to invest. This approach is a new paradigm that takes into account tangible and intangible elements (Brondoni, 2010, Risso, 2012). The assumption of environmental and social responsibility can create the basis for a firm's success. In this sense, the evidence of the continuity between a "good corporate responsibility and good corporate governance" is realized by the incorporation of CSR into daily operations and financial strategies, that is a concrete and full development of CSR (EU Resolution, 2013; Salvioni \& Bosetti, 2014). In this sense, both from an instrumental and a normative perspective, the implementation of CSR is justified as a strategic instrument for improving financial performance and as a moral pressure over and care of stakeholder needs (Asif et al., 2011).

The aim of the paper is to frame the purposes and goals of integrated reporting, highlighting the extent of integration between reports that differ in their focus and nature, allowing more readability and comprehensibility of financial and nonfinancial information by all groups of stakeholders. The focus will be put on the impacts that integrated reporting generates at the governance level and how new sets of transparent and intelligible information shared with stakeholders favor their engagement and allow the understanding of the social role that the company was always asked to play but has not always properly communicated. This analysis will 
highlight how, by implementing integrated reporting, a company might enhance its performances, increase its market rating, and generate growing value, both in perception and financially. The article is structured as follows: the next section presents some developments of the concept of CSR and the integration of social and environmental instances in an enterprise's culture. It will be explained how the concept of standards of responsibility representation has changed over time and has positive and critical elements. The Italian Decree n. 254 on December 30, 2016, which implements the European Directive, will be analyzed in the third section, highlighting several unique elements. According to the norm, Italian enterprises have the opportunity to choose or build their own reporting tool. The law stimulates, in this logic, the sensitivity of the individual economic actors and-according to the European Directive-allows the drawing up of integrated reporting to enterprises who are not obliged by the law. Such perspective could be a great and interesting opportunity to spread sustainable approaches in the extensive field of small and medium enterprises (SMEs).

\section{CSR Standards: From Compliance to Integration}

"The vibrantly growing stream of research on CSR" (Jamali \& Carroll, 2017) is biunivocally linked to the abovementioned increasing social role played by enterprises (Salvioni \& Bosetti, 2014). Campbell (2007) argues that corporations are more socially responsible if they operate in an environment where important publications, business school curricula, and other educational venues institutionalize the need for such comportments. There is a correlation between research, training, and implementation on these topics: the first two record and describe the observed state and, at the same time, stimulate the penetration of connected culture. According to Visser and Kymal (2015), business is a "part of the solution to our global challenges, rather than part of the problem." The authors consider some theories as the foundations of integrated value creation (IVS), which they define as a tool for innovation and transformation. The evolution of concepts about business ethics and responsibility, among which stakeholder theory (Freeman, 1984), triple bottom line (Elkington, 1994), and the creation of shared value (Porter and Kramer, 2011) lead to this new approach to "how" integrate. Between the seven steps of the IVC, integrated reporting is crucial and essential, as "is what will ensure that implementation is happening and that the company stays on track to achieve its transformational goals" (Visser \& Kymal, 2015).

In this scenario, the thus far illustrated need for information-integrating financial and non-financial data - cannot be satisfied by traditional reporting models because of the number and nature of dimensions that are different, partly new, or thus far not considered in an integrated way-corporate governance, sustainability, etc. (GarcíaSánchez \& Noguera-Gámez, 2017; Jamali \& Carroll, 2017). Good practices in corporate governance are associated with the quantity and quality of enterprise disclosure (Venter et al., 2017), and many authors underline a causal relationship between the implementation of integrated reporting, a social recognition (Campopiano \& De Massis, 2014), and a long-term continuity in investment (Serafeim, 2015). Although this approach is residual, as it is not integrated and limited to the enterprise's point of view, many authors recognize the benefits, 
strategic advantage, and increase in financial performance that derive from the implementation of CSR policies (Corazza et al., 2017; Campopiano \& de Massis, 2014; Besser, 2012; Porter \& Kramer, 2011; 2006; Jamali \& Mirshak, 2007; Perrini \& Vurro, 2006; Brondoni, 2003; Margolis \& Walsh, 2003; Burke \& Logsdon, 1996). This would not be possible-or would be more complex-without adequate reporting tools, which thus become not merely marginalized instruments, but strategic factors for communication and expressions of choices in and even support for the governance. Between strategic benefits, reporting CSR actions in particular is a key factor for high visibility and good reputation (Campopiano \& de Massis, 2014; Young and Marais 2011; Fombrun et al. 2000), as it becomes a kind of selfobservation for enterprises (Perrini \& Vurro, 2013).

The subject of standards in reporting raises some concerns and critical issues. A fundamental element is expressed by Asif et al. (2011): the measurement of CSR is based on "the axiom "what gets measured, gets managed"": it is necessary that the activities described derive from policies that are really adopted, with quantifiable evidence. This implies an approach not only compliant to standards: it concerns policies actually realized as well as the possibility to record any results. It is, according to Perrini and Vurro (2013), a matter of new skills: the increasing number of stakeholders complicates business decisions connected to their instances. This new situation calls for the capability to analyze stakeholders (Asif et al., 2011) and through reporting - to inform about the responsibility spectrum and effectiveness in relationships (Perrini \&Vurro, 2013). According to de Colle et al. (2014:178), CSR standards are an "intricate jungle" with several drawbacks:

- the obsession with compliance, as an excess of conformity and a lack of flexibility

- the over/miscommunication of data, as the loss of focus on purposes in communicating data and, on the contrary, the insurgence of a "carpet-bombing syndrome" (Elkington, 2002)

- the reduction of measures of results to proxies due to the impreciseness of dimensions of CSR standards and their immeasurability.

Salvioni and Bosetti (2014) identify some difficulties associated with the assortment of information and risk of redundancy in addition to considerable requirements for investment and training.

The concept of integrated reporting emerged first in South Africa in 1994; the first experiments were followed by the foundation of the International Integrated Reporting Committee (IIRC) in 2010, which was then renamed to the International Integrated Reporting Council in 2012. In 2013, this group published the international integrated reporting framework. According to Richard Howitt, Chief Executive Officer of the International Integrated Reporting Council, "it helps reporting to become a tool for understanding and quantifying long-term value rather than a boxticking exercise to satisfy governments and regulators" (KPMG, 2017:25). The IIRC defines an integrated report as "a concise communication about how an organization's strategy, governance, performance and prospects, in the context of its external environment, lead to the creation of value over the short, medium and long term" (IIRC, 2013). The concept of integration goes beyond the tool for disclosing information and extends up to an "integrated thinking" (IT). The concept frames "the active consideration by an organization of the relationships between its [...] units and the capitals that the organization uses or affects" (IIRC, 2013:2). Capitals 
chosen by the IIRC are financial, manufactured, intellectual, human, social, relational, and natural and represent stocks of value that a firm's activities can increase or decrease. The aim of IT is the combination of decisions and actions to create value over the short, medium, and long term.

The use of this report is remarkable in numerical terms. Two thirds of enterprises studied in the KPMG CSR Report 2017 have used it for integrated reporting and reflect the concept at the base of the integrated approach: the framework "does not prescribe specific key performance indicators (KPIs), measurement methods or the disclosure of individual matters. Those responsible for the preparation and presentation of the integrated report therefore need to exercise judgement, given the specific circumstances of the organization" (IIRC, 2013).

\section{Integrated Reporting in Italy}

In their recent analysis of the Italian state in relation to the integrated reporting, Gesuele and Pozzoli (2017) underline two fundamental goals of what they define as the last frontier of communication. The first aim of the integrated report is to assemble financial and non-financial information to stimulate an external judgment on performance and value creation over time.

The second is related to empowerment and legitimation: the document orients the firm's management and gives evidences of positive outputs from enterprises. Integrated reporting is functional for disclosure (D'Este et al., 2013), supports systematic management, and reflects a real integration of the above-presented dimensions. The application of integrated reporting in Italy is very limited: according to Camodeca and Almici (2017), only 6 Italian listed companies out of 338 are presently applying it. The condition is next to change due to a new norm coming into force. As mentioned above, the Legislative Decree n. 254 of December 30, 2016 is the implementation of Directive 2014/95/EU of the European Parliament and of the Council. The legal instrument makes some amendments to the previous Legislative Decree n. 58 of February 24, 1998 ("Testo unico delle disposizioni in materia di intermediazione finanziaria") adding the reference to diversity policies (in paragraph 2, letter "d-bis"). In compliance with the European Directive requirements: "reference to the average number of employees, balance sheet total and net turnover," the addressees of the decree are as follows:

1. public interest entities ${ }^{i}$, which have had on average, during the year, a number of employees greater than 500 and have exceeded one of these two limits:

a) $€ 20$ million of balance sheet,

b) $€ 40$ million of net revenue (sales and services);

2. parent company of a large group.

In the first case, the enterprise will have to produce a non-financial individual statement, while in the second case, the report will be consolidated, including data about parent and subsidiary companies.

The Directive 2014/95/EU has indicated the following requirements for the nonfinancial statement for large undertakings: "containing information relating to at least environmental matters, social and employee-related matters, respect for human rights, anti-corruption and bribery matters [...] a description of the policies, outcomes and risks related to those matters [...]. The non-financial statement should 
also include information on the due diligence processes implemented by the undertaking, also regarding, where relevant and proportionate, its supply and subcontracting chains [...]”'.

In the event that firms are required to prepare a non-financial statement, the EU defines the following contents to be considered: environmental matters, health and safety, renewable/non-renewable energy, the use of resources, gender equality, working and social conditions, and the impact and development of local communities.

In applying the European standard, the Italian decree maintains the same items listed above and tracks the direction to follow: "assicurare la comprensione dell'attività d'impresa, del suo andamento, dei suoi risultati e dell'impatto dalla stessa prodotta" (to ensure the understanding of the business activity, its performance, its results, and the impact of its products).

This must be done by describing at least: activities;

a) the business model for the management and organization of business

b) the policies pursued by the undertaking, the results achieved through them, and the relevant key indicators of non-financial performance;

c) the main risks arising from or arising out of the abovementioned issues deriving from the activities of the undertaking.

Two main central issues emerge: the relationship between the business modelthat is the guide structure of the enterprise-and the governance behaviors compared to the issues on which the norm insists. This, in fact, represents the most direct connection between currently established elements and the real implementation in business' practices and operations. The clearer-due to being closer to the actual implementation - such a description is, the more effective the reporting tool will be. The choice of key indicators, in this sense, is a delicate passage. For instance, de Colle et al. (2014) exemplify the risk by describing training: the number of hours per employee provided by an organization is not exhaustive, as they do not describe the quality of teachings or enhance knowledge.

Regarding the placement and therefore the visibility given to the statement, two solutions are proposed. The first option is to include it in the management report ${ }^{\mathrm{ii}}$, marking the new section that would be created. The other possibility is the creation a separate report, also marked as in the section of the above report. Even if there is a choice between the two options, the need to emphasize compliance is equally clear. This is, on the one hand, a purely normative indication, but, on the other hand, it becomes a guide in consulting the document. The result, in any case, is the immediate readability of information integrated in this new model. The non-financial report is published, together with the management report, in the Business Register. The required contemporaneity is a sign of the will to integrate, avoiding the physical and temporal gap or data dispersion. Conversely, these are immediately available and can be linked, with a view to constantly tracking the achieved results, eventually with the opportunity to analyze trends over the years.

Since the introduction of the Decree is recent, it is necessary to wait for the publication of the documents related to 2017 to make a nationwide assessment of novelties brought about by the law.

It will be interesting to see what main standard will be chosen. The EU Directive suggests "national frameworks, Union-based frameworks such as the Eco- 
Management and Audit Scheme (EMAS), [...] international frameworks such as the United Nations (UN) Global Compact, the Guiding Principles on Business and Human Rights [...], the Organisation for Economic Co-operation and Development (OECD) Guidelines for Multinational Enterprises, the International Organisation for Standardisation's ISO 26000, the International Labour Organisation's Tripartite Declaration of principles [...], the Global Reporting Initiative, or other recognised international frameworks."

The Italian Decree n. 254 admits standards and guidelines issued by supranational, international, or national bodies of a public or private nature in the measure where they are appropriate to the EU instances. In the same way, is possible to apply an "independent reporting methodology": a composite set consisting of one or more reporting standards and of additional performance principles, criteria, and indicators, individually identified and supplementary to those already set out in the adopted standards. The choice of a specific standard would validate the usability of such framework or highlight weaknesses or limitations in terms of practicality or resources needed to set up a conforming relationship. If another option were to emerge, it would probably reflect local cultural peculiarities. If, finally, the majority or a significant number opted for a stand-alone model, it would be necessary to deepen the analysis to identify the structural features-limited probabilities-and to understand the motivation behind the choice.

European disclosure requirements apply only to some large undertakings and groups, in accordance with the principle "think small first" (EU, 2014). Such orientation clearly has the goal of not aggravating the activity and interfering with resources of SMEs. Likely due to the particular national entrepreneurial contextstrongly characterized by the presence of SMEs-the Italian Decree offers the integrated reporting opportunity to different economic actors not included in the law: "i soggetti diversi da quelli ricompresi nell'ambito di applicazione [...] che, su base volontaria, redigono e pubblicano dichiarazioni individuali o consolidate non finanziarie e che si attengono a quanto disposto dal presente decreto legislativo, possono apporre su dette dichiarazioni la dicitura di conformità allo stesso" (other different subjects [...] that voluntarily prepare and publish individual or consolidated non-financial statement and that comply with the legislative decree, may insert a declaration of conformity to the decree).

This is a remarkable opportunity, as the capillary geographic and numerical distribution of SMEs potentially extends the aims of the Decree. In addition to the increasing compliance with the standard, the most important result has two implications. First, the dissemination of the culture underlying the application of

European legislation allows its acquisition in the most distinctive sector of the economic national scenario. Second, SMEs, for their particular characterization and uniqueness, can identify models, integrations, and specific reporting solutions that can become replicable good practices in other contexts and business dimensions as well. In any case, this is, at national level, a major challenge whose effectiveness will arise if the application of the Decree will not be interpreted in a residual way as merely compliance, but as a "constructive and evolutionary vision of the nonfinancial statement" (Zambon, 2017).

\section{Conclusions and Emerging Issues}


New instances within the current globalized scenario require enterprises' contribution to the construction of welfare by repositioning their role in society. Combining environmental and social instances in business activities responds to and calls for demonstrating the response to emerging needs. It highlights the capability to contribute to sustainable growth over time and to share value with stakeholders. This requires new communication actions, among which the integrated report is a tool that integrates various instances and gives visibility to governance choices and actions consistent with a new business function.

The study was meant to contextualize the European legislation and its recent application at the national level, highlighting its goals and opportunities. Many remarkable issues arise that will be interesting to analyze when the first documents required by law are available. First, it will be crucial to understand which tools and standards will be used by firms to keep or build effective relationships with their stakeholders. At the same time, SMEs' choice to voluntary adhere to the regulatory guidelines might be a testbed for the diffusion of a culture geared toward sustainable development. Flexible models and good practices emerging from SMEs could be replicable even in firms of different dimensions and contexts. Surely, a content analysis of reports produced by the end of 2017 will be enlightening to understand how companies consider themselves with respect to identified issues and to what extent the new social function of companies is actual.

According to de Colle et al. (2014), this moment must be considered a milestone for "organizational self-discovery," understanding that the legal requirement of evidence of a sustainable business approach goes beyond the question, "Am I following the rule?" and must lead to, "Am I doing the right thing?"

\section{Bibliography}

Asif M., Searcy C., Zutshi A., Fisscher O. A. M. (2011) An integrated management systems approach to corporate social responsibility, Journal of Cleaner Production, 1-1.1 http://dx.doi.org/10.1016/j.jclepro.2011.10.034

Besser T. L. (2012) The consequences of social responsibility for small business owners in small towns, Business Ethics: A European Review, n. 21(2). http://dx.doi.org/10.1111/j.1467-8608.2011.01649.x

Brondoni S. M. (2014) Global Capitalism and Sustainable Growth. From Global Products to Network Globalisation, Symphonya. Emerging Issues in Management (symphonya.unimib.it), 1, 10-31. http://dx.doi.org/10.4468/2014.1.02brondoni

Brondoni S. M. (2010) Intangibles, Global Networks \& Corporate Social Responsibility, Symphonya. Emerging Issues in Management (symphonya.unimib.it), 2, 6-24. http://dx.doi.org/10.4468/2010.2.02brondoni

Brondoni S. M. (2003) Network Culture, Performance \& Corporate Responsibility, Symphonya. Emerging Issues in Management (symphonya.unimib.it), 1, 8-24.

http://dx.doi.org/10.4468/2003.1.02brondoni

Brundtland G. H. (1987) Our common future - Call for action, Environmental Conservation, 14(4), 291-294.

https://doi.org/10.1017/S0376892900016805

Burke L., Logsdon J. M. (1996) How corporate social responsibility pays off. Long range planning, 29(4), 495-502.

https://doi.org/10.1016/0024-6301(96)00041-6

Camodeca R., Almici A. (2017) Implementing Integrated Reporting: Case Studies from the Italian Listed Companies. Accounting and Finance Research, 6(2).

http://dx.doi.org/10.5430/afr.v6n2p121 
Campbell, J. L. (2007), Why would corporations behave in socially responsible ways? An institutional theory of Corporate Social Responsibility, Academy of Management Review, 32(3), pp. 946-967. http://dx.doi.org/10.5465/AMR.2007.25275684

Campopiano G., De Massis A. (2015) Corporate social responsibility reporting: A content analysis in family and non- family firms, Journal of Business Ethics, 129(3), 511-534.

http://dx.doi.org/10.1007/s10551-014-2174-z

Carney, M., Gedajlovic, E., Sur, S. (2011) Corporate governance and stakeholder conflict, J Manag Gov (2011) 15:483-507

Corazza L., Scagnelli S. D., Mio C. (2017) Simulacra and Sustainability Disclosure: Analysis of the Interpretative Models of Creating Shared Value, Corporate Social Responsibility and Environmental Management, 24, 414-434. http://dx.doi.org/10.1002/csr.1417

Cruz J.M., Matsypura D. (2009) Supply chain networks with corporate social responsibility through integrated environmental decision-making, International Journal of Production Research, 47(3), $621-648$ http://dx.doi.org/10.1080/00207540701513901

D’Este C., Fellegara A., Galli D., di Piacenza G. (2012) Livelli di disclosure economico-finanziaria e scelte di integrated reporting nei gruppi a connotazione territoriale. Università Cattolica del Sacro Cuore-Piacenza.

de Colle, S., Henriques, A., Sarasvathy, S. (2014). The Paradox of Corporate Social Responsibility Standards, Journal of Business Ethics, 125, 177-191.

de Colle S., Henriques A., Sarasvathy S. (2014) The paradox of corporate social responsibility standards, Journal of Business Ethics, 125(2), 177-191. http://dx.doi.org/10.1007/s10551-013-1912-y

Elkington J. (2002) Trust us: The 2002 Global Reporters Survey of Corporate Sustainability Reporting, SustainAbility, London.

EU Directive (2014). Directive 2014/95/EU of the European Parliament and the Council of 22 October 2014 amending Directive 2013/34/EU as regards disclosure of non-financial and diversity information by certain large undertakings and groups. EU L 330: 1-9

EU Directive (2013). Directive 2013/34/EU of the European Parliament and of the Council of 26 June 2013 on the annual financial statements, consolidated financial statements and related reports of certain types of undertakings, amending Directive 2006/43/EC of the European Parliament and of the Council and repealing Council Directives 78/660/EEC and 83/349/EEC Text with EEA relevance.

EU Resolution (2013). European Parliament resolution of 6 February 2013 on corporate social responsibility: accountable, transparent and responsible business behaviour and sustainable growth

EU Communication (2011). Communication from the Commission to the European Parliament, the Council, the Economic and Social Committee and the Committee of the Regions Single Market Act Twelve levers to boost growth and strengthen confidence "Working together to create new growth".

Fombrun C. J., Gardberg N. A., Sever J. M. (2000) The Reputation QuotientSM: A multi-stakeholder measure of corporate reputation, Journal of brand management, 7(4), 241-255.

https://doi.org/10.1057/bm.2000.10

Freeman R. E., Parmar B. L. (2017) Managing for Stakeholders and the Purpose of Business, Darden Case

Freeman R. E., Harrison J. S., Wicks A. C., Parmar B. L., de Colle S. (2010) Stakeholder Theory: The State of the Art, Cambridge University Press, New York.

https://doi.org/10.1080/19416520.2010.495581

García-Sánchez I. M., Noguera-Gámez L. (2017) Integrated Reporting and Stakeholder Engagement: The Effect on information Asymmetry, Corporate Social Responsibility and Environmental Management, 24, 395-413. http://dx.doi.org/10.1002/csr.1415

Gesuele, B., \& Pozzoli, M. (2017). L'utilizzo del Integrated Reporting in Italia. Stato dell'arte, Economia Aziendale Online 2000 Web, 8(2), 119-129.

http://dx.doi.org/10.13132/2038-5498/8.2.119-129

International Integrated Reporting Council (IIRC) (2013) The international <IR $>$ framework. http://integratedreporting.org/wp-content/uploads/2013/12/13-12-08-THEINTERNATIONAL-IRFRAMEWORK-2-1.pdf 
Italian Parliament (2016) Decreto Legislativo 30 dicembre 2016, n. 254. Attuazione della direttiva 2014/95/UE del Parlamento europeo e del Consiglio del 22 ottobre 2014, recante modifica alla direttiva 2013/34/UE per quanto riguarda la comunicazione di informazioni di carattere non finanziario e di informazioni sulla diversità da parte di talune imprese e di taluni gruppi di grandi dimensioni.

Italian Parliament (1998) Decreto Legislativo 24 febbraio 1998, n. 58. Testo unico delle disposizioni in materia di intermediazione finanziaria, ai sensi degli articoli 8 e 21 della legge 6 febbraio 1996, 52.

Jamali D., Mirshak R. (2007) Corporate social responsibility (CSR): Theory and practice in a developing country context. Journal of business ethics, 72(3), 243-262.

https://doi.org/10.1007/s10551-006-9168-4

Jamali D., Carroll A. (2017) Capturing advances in CSR: Developed versus developing country perspectives, Business Ethics: A Eur Rev., 26, 321-325.

http://dx.doi.org/10.1111/beer.12157

KPMG (2017) Survey of Corporate Responsibility Reporting 2017.

https://home.kpmg.com/content/dam/kpmg/campaigns/csr/pdf/CSR_Reporting_2017.pdf

Margolis J. D., Walsh, J. P. (2003) Misery loves companies: Rethinking social initiatives by business, Administrative science quarterly, 48(2), 268-305.

Mervelskemper L., Streit D. (2017) Enhancing Market Valuation of ESG Performance: Is Integrated Reporting Keeping its Promise?, Business Strategy and the Environment, 26, 536-549. http://dx.doi.org/10.1002/bse.1935

Müller S., Stawinoga M.,Velte P. (2015) Stakeholder expectations on CSR management and current regulatory developments in Europe and Germany, Corporate ownership and control, n. 12, pp. 505512 .

http://dx.doi.org/0.22495/cocv12i4c4p8

Perrini F., Vurro C. (2013) Stakeholder Orientation and Corporate Reputation: A Quantitative Study on US Companies, Symphonya. Emerging Issues in Management (symphonya.unimib.it), 1, 1-13 http://dx.doi.org/10.4468/2013.1.04perrini.vurro

Porter M. E., Kramer M. R. (2011) Creating shared value, Harvard Business Review, JanuaryFebruary, pp. 62-77.

Porter M. E., Kramer M. R. (2006) The link between competitive advantage and corporate social responsibility. Harvard Business Review, 84(12), 78-92.

Risso M. (2012) Exploring Partnership for Social Innovation, Symphonya. Emerging Issues in Management (symphonya.unimib.it), 2, 26-36. http://dx.doi.org/10.4468/2012.2.03risso

Salvioni D. M., Astori R. (2013), Sustainable Development and Global Responsibility in Corporate Governance, Symphonya, Emerging Issues in Management (symphonya.unimib.it), 1, 2013, 28-52 http://dx.doi.org/10.4468/2013.1.03salvioni.astori

Salvioni D. M, \& Bosetti L. (2014) Sustainable Development and Corporate Communication in Global Markets, Symphonya. Emerging Issues in Management (symphonya.unimib.it), 1, 32 - 51. http://dx.doi.org/10.4468/2014.1.03salvioni.bosetti

Serafeim, G. (2015), Integrated Reporting and Investor Clientele, Journal of APPLIED CORPORATE FINANCE, 27(2).

http://dx.doi.org/10.1111/jacf.12116

Sierra-Garcia L., Zorio A., García-Benau M. A. (2015) Stakeholder engagement, corporate social responsibility and integrated reporting: an exploratory study, Corp. Soc. Responsib. Environ. Manag., 22, 286-304. http://dx.doi.org/10.1002/csr.1345

Southwell C (2004) Engaging SMEs in community and social issues. In Spence L.J., Habisch A., Schmidpeter R. (2004) Responsibility and Social Capital: The World of Small and Medium Sized Enterprises. Basingstoke: Macmillan, 96-111.

United Nations (2014) Synthesis report of the Secretary-General on the post-2015 sustainable development agenda, the road to dignity by 2030: ending poverty, transforming all lives and protecting the planet.

Yawar S. A., Seuring S. (2017) Management of social issues in supply chains: a literature review exploring social issues, actions and performance outcomes. Journal of Business Ethics, 141(3), 621643.

https://doi.org/10.1007/s10551-015-2719-9 
Venter E. R., Stiglingh M., Smit A. R. (2017) Integrated Thinking and the Transparency of Tax Disclosures in the Corporate Reports of Firms, Journal of International Financial Management \& Accounting, 28, 3 http://dx.doi.org/10.1111/jifm.12064

Vitolla F., Rubino M., Garzoni A. (2016) Integrated corporate social responsibility, Journal of Management Development, 35(10), 1323-1343.

https://doi.org/10.1108/JMD-08-2015-0113

Visser W., Kymal C. (2015) Integrated value creation (IVC): beyond corporate social responsibility (CSR) and creating shared value (CSV), Journal of International Business Ethics, 8(1), 29.

Vurro, C., Russo, A., Costanzo, L. A. (2014) Sustainability along the Value Chain: Collaborative Approaches and their Impact on Firm Performance, Symphonya. Emerging Issues in Management (symphonya.unimib.it), 2, 30 - 44 .

http://dx.doi.org/10.4468/2014.2.04vurro.russo.costanzo

Young S., Marais, M. (2011) CSR reporting: An Institutional perspective. Finance and Corporate Governance Conference, La Trobe University.

Zambon S. (2017) Dal D. Lgs. n. 254/2016 alla rappresentazione della creazione di valore. NIBRDeloitte "Il D.Lgs. n. 254/2016" sulle non-financial information, Milano 25/10/2017.

\section{Notes}

i Those in the Article 16(1) of Legislative Decree n. 39 of January the $27^{\text {th }} 2010$

ii Whith reference to Article 2428 of the Italian Civil Code, Article 41 of Legislative Decree n. 136 (18 August 2015), Article 94 of Legislative Decree n. 209 (7 September 2005) 